\title{
Kalām in the crossfire: A historical survey of the legitimacy of the study of theology within the Sunni school of Islam
}

\begin{tabular}{|c|c|}
\hline \multicolumn{2}{|c|}{$\begin{array}{l}\text { Authors: } \\
\text { Nafiseh F. Moghaddas }{ }^{1} \text { (]) } \\
\text { Sayyid M. Yazdani }{ }^{-10}\end{array}$} \\
\hline \multicolumn{2}{|c|}{$\begin{array}{l}\text { Affiliations: } \\
\text { }{ }^{1} \text { Department of Ahl-al-Bayt } \\
\text { Studies, Faculty of Theology } \\
\text { and Ahl-al-Bayt Studies, } \\
\text { University of Isfahan, } \\
\text { Isfahan, Iran }\end{array}$} \\
\hline \multicolumn{2}{|c|}{$\begin{array}{l}{ }^{2} \text { Department of Islamic } \\
\text { Denominations, Faculty of } \\
\text { Islamic Denominations, } \\
\text { University of Religions and } \\
\text { Denominations, Qom, Iran }\end{array}$} \\
\hline \multicolumn{2}{|c|}{$\begin{array}{l}\text { Corresponding author: } \\
\text { Nafiseh Moghaddas, } \\
\text { n.faghihi@ahl.ui.ac.ir }\end{array}$} \\
\hline \multicolumn{2}{|c|}{$\begin{array}{l}\text { Dates: } \\
\text { Received: } 14 \text { June } 2021 \\
\text { Accepted: } 15 \text { Aug. } 2021 \\
\text { Published: } 08 \text { Nov. } 2021\end{array}$} \\
\hline \multicolumn{2}{|c|}{$\begin{array}{l}\text { How to cite this article: } \\
\text { Moghaddas, N.F. \& } \\
\text { Yazdani, S.M., 2021, 'Kalām } \\
\text { in the crossfire: A historical } \\
\text { survey of the legitimacy } \\
\text { of the study of theology } \\
\text { within the Sunni school } \\
\text { of Islam', HTS Teologiese } \\
\text { Studies/Theological Studies } \\
77(4), \text { a6917. https://doi. } \\
\text { org/10.4102/hts.v77i4.6917 }\end{array}$} \\
\hline \multicolumn{2}{|c|}{$\begin{array}{l}\text { Copyright: } \\
\text { (c) 2021. The Authors. } \\
\text { Licensee: AOSIS. This work } \\
\text { is licensed under the } \\
\text { Creative Commons } \\
\text { Attribution License. }\end{array}$} \\
\hline \multicolumn{2}{|l|}{ Read online: } \\
\hline 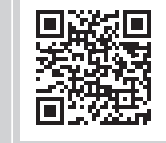 & $\begin{array}{l}\text { Scan this QR } \\
\text { code with your } \\
\text { smart phone or } \\
\text { mobile device } \\
\text { to read online. }\end{array}$ \\
\hline
\end{tabular}

The aim of this article is to briefly introduce and to examine the views of the founders of the four Sunni schools of Islamic jurisprudence (namely, Abū Hanīfa Nu'mān ibn Thābit, Mālik ibn Anas, Muhammad ibn Idrīs al-Shāf'⿳亠丷⿵冂⿱八口𧘇, and Ahmad ibn Hanbal) and that of their renowned students and followers, regarding the legitimacy of engaging in the study of Islamic doctrinal beliefs or Kalām. Different, and often conflicting, views have been postulated on this matter. Some Sunni thinkers have condemned the pursuit of theology as an act of heresy and denounced its practitioners as apostates. Other Sunni thinkers have extolled this discipline as the noblest of sciences whose learning and teaching are, at least under certain circumstances, incumbent. This fundamental dispute regarding the legitimacy of the discipline of theology has resulted in a rather contentious and opaque scholarly environment. In addition to the inherent importance of the discipline of theology as such, the significance of this dispute is compounded by the impact that the attitude one adopts toward this discipline can have on the development of the intellectual and rational aspects of Islam. A negative attitude toward theology, for example, can hamper the application of rational elements to Islamic doctrine. Our focus in this article is on analysing the views of the leading thinkers and jurists of the Sunni school and investigating the most authoritative sources of doctrinal tradition within this major denomination of Islam. Our study leads us to conclude that the disapproving views of the preeminent Sunni figures should be construed, not as a denunciation of the discipline of theology per se, but as a refutation of certain theological principles and persuasions that are viewed as incompatible with orthodox Islamic faith. In addition to and preceding that conclusion, this article provides a survey of the literature concerning the views of Muslim scholars on the legitimacy of Kalām. After categorising these views into the two opposite camps of Kalam's legitimacy and illegitimacy, the article then proceeds to evaluate and critically analyse them, and to resolve some of their initial incompatibilities.

Contribution: The article sheds new light on the historical development of the discipline of theology within the Sunni schools of Islam. This is a little-studied and often overlooked subject that can help in attaining a better understanding of how this critical field within religious studies has emerged into its present form.

Keywords: the Sunni school; kalam; theology; disputation; the Mu'tazilah; the Ashā'irah; the Māturīdìyyah; the Ahl al-Hadīth; credal theology; dogmatic theology.

\section{Introduction}

The branch of traditional religious studies in Islam that deals with religious belief and doctrine is designated as kalām, but it is also referred to by such other descriptive titles as: al-figh al-akbar ('the greatest knowledge'), 'ilm al-tawhīd ('the science of divine unity') (see Taftāzānī1401 AH, 1:6), 'ilm ușūl al-dīn ('the science of the principles of faith') (see Ibn Athīr Jazarī $1400 \mathrm{AH}, 3: 161$ ), 'ilm sharī'at ('the science of the path of faith'), and 'aqlìyāt ('the rational principles') (see Ibn Taymīyah 1425 $\mathrm{AH}, 19: 307)$. Shahrastānī claimed that the use of the appellation kalām to designate this discipline was first employed by Mu'tazilī theologians (Shahrastānī 1404 AH, 1:30). The function of this discipline consists of proving and articulating the principal doctrines of faith - including postulating the facts that constitute the believer's knowledge of God, shedding light on how obedience to God can be manifested, expounding on the nature of divine prophecy and the character of God's prophets - and defending the 'boundaries' of faith against the criticisms posed by disbelieving sceptics (see Muzaffar $1422 \mathrm{AH}, 1: 19$ ). As such, kalām covers all doctrinal beliefs of Islam, and is not restricted to the study of God and divine attributes. (Kalām and its domain are 
to be more elaborately defined in a separate section of the article.)

The aim of this article is to analyse the views of Muslim thinkers regarding the legitimacy or illegitimacy, of the study of Kalām, and why its practitioners have been denounced as heretics and apostates by some major Muslim figures. The question of the legitimacy of studying and practising theology has historically led to great controversy. On one side of this controversy were those who declared the pursuit of this discipline to be contrary to genuine faith, even going so far as to equate it with kufr (disbelief) and zindiqah (atheism). On the opposite side of the dispute (Anșānī Hirawī 1418 AH, 5:71; Ibn Taymiyya 1425 AH, 16:473; Dāremī 1433 AH, 33) were those who pronounced engagement in this discipline and teaching it to others as a meritorious (Qīrwānī n.d.:169; Ghazālī n.d., 1:96-97) and even occasionally mandatory endeavour (Bayāộ̄ 1425:33-37; Ibn Abī al-'Izz 1391 AH, 1:65). The views of the representatives of each side will be discussed below.

Considering the fact that what is intuitively expected of all devout Muslims is that they should endorse and support this discipline, as its essential function is defending the fundamental articles of Islamic faith, the question naturally arises as to why some major Muslim figures have taken such a negative stance toward the discipline of kaläm? What compelled them to assume such a position? Is it in fact the discipline of theology as such that is the object of their condemnation? Or is it a particular subgroup of Islamic theologians that are intended? Or could it be that this stance was in response to certain topics and discussions that proved distasteful to the religious sensibilities of the detractors?

To answer these questions, we examine the views of the proponents and detractors of kalām, focusing primarily on the views of the imams of the four main Sunni schools of jurisprudence and their prominent students and followers. The conclusion we arrive at is that the occasional condemnation of theologians and the prohibition on the study of kalām were not directed per se at the discipline as we know it. Rather, the detractors were primarily opposed to certain theological questions and principles, and therefore denounced only a certain group and a certain persuasion of theologians in virtue of their position on these problematic questions and principles.

\section{Historical background of the present study}

Throughout the history of Islamic scholarship, numerous books have been produced on the question of whether it is permissible to pursue kalām. The following is a short list of some of the most preeminent of these works:

- Risālat al-ghunyah 'an al-kalām wa ahlih ("The Dispensability of Kalām and Its Practitioners'), by Abū Sulaymān Khațābī (d. $388 \mathrm{AH})$.
- Ahādīth fī dhamm al-kalām wa ahlih ('Reports Denouncing Kalām and Its Practitioners'), by Aḥmad Rāzī (d. 454 AH), also known as Muqirrī.

- Dhamm al-kalām wa ahlih ('Denunciation of Kalām and Its Practitioners'), by Khwājah 'Abdullāh Anșārī Harawī (d. $1489 \mathrm{AH})$.

- Al-Intișār li aṣhāabal-ḥadìth ('Triumph of the Ahl al-Hadīth'), by Sam'ānī Shāfi'ī (d. 489 AH).

- Iljām al-'awām 'an 'ilm al-kalām ('Protecting the People from the Science of Kalām'), by Abū Hāmid Ghazālī (d. $505 \mathrm{AH})$.

- Nahāyat al-aqdām fī 'ilm al-kalām ('The Greatest Advancement in the Science of Kalām'), by Muhammad Shahrastān̄i (d. 548).

- Tahrīm al-nazar fī kutub al-kalām ('Expounding the Impermissibility of Reading the Books of Kalām'), Ibn Qudāmah Maqdisī (d. 620 AH).

- Al-Radd 'alà al-mantíqīyyìn ('Refutation of the Logicians'), by Ibn Taymīyyah (d. $728 \mathrm{AH})$.

- Sawn al-mantiq wa al-kalām 'an fannay al-manțiq wa al-kalām ('Safeguarding Language and Speech from the Disciplines of Logic and Kalām'), by Suyyūṭī (d. 911).

The central theme in all of the above texts is the illegitimacy of kalām and the impermissibility of studying it. However, there are not that many texts written in defence of this discipline. One notable work that offers such a defence is Risālat istihsān al-khaw fị 'ilm al-kalām ('Treatise on the Merits of Engaging in the Discipline of Kalām'), whose authorship is commonly credited to Abū al-Hasan Ash'arī (d. 324), the eponymous founder of the Ash'arī school of Sunni theology. (The latter work is in some sources identified with the alternative title Risālat fì al-radd 'alā man zanna anna al-ishtighāl bi al-kalām bid'ah ['Treatise Countering Those Who Denounce the Pursuit of Kalām as Heresy'].)

The topic of this article is one that has in large part been ignored by contemporary scholars. In spite of our fairly exhaustive efforts, we were only able to find two articles written on this topic: 'Ilm al-kalām bayn al-dhamm wa al-madīh' ('The Science of Kalām in the Crossfire of Condemnation and Praise'), by Aḥmad Sāmiḥ 'Alī (in the journal Minhāj), and ' $\mathrm{Ilm}$ al-kalām wa hukm al-ishtighāl bih' ('The Science of Kalām and the Rule concerning its Pursuit'), by Maḥūz Sālim (in the journal Dirāsāt al-jazâa'ir). In addition to lacking an analysis and appraisal of the various views on this question, the two aforementioned articles have also failed in offering a comprehensive survey of all the articulated views on this question, be it those of the proponents of kalām or its critics. (For instance, such a prominent figure as Abū Hanīfah is conspicuously absent from both articles.) As such, the present article came about as an attempt to address this question in a more comprehensive and analytic manner. To this end, we have investigated numerous sources and have endeavoured to evaluate the views of the major Islamic thinkers on this very important question in a fair and academically objective manner. 


\section{Defining Kalām}

Kalām has numerous definitions. They vary between a minimalist concept of kalām and a maximalist one. One representative example that falls into the former category is the definition offered by Taftāzānī: 'Comprehending religious beliefs by virtue of indubitable arguments' (Taftāzānī 1410 $\mathrm{AH}, 1: 6)$. Another such definition is that proffered by $\overline{\mathrm{I}} \mathrm{j} \overline{\mathrm{i}}$. The stress in his definition is primarily on the function of the discipline of kalām in proving religious beliefs (see $\overline{\mathrm{I}}_{\mathrm{j}} \overline{\mathrm{T}}$ $1417 \mathrm{AH}, 1: 31)$. Ibn Khaldūn's definition exemplifies the maximalist conceptualisation of kalām. He defined kalām as:

[T] he science that defends religious beliefs by virtue of rational arguments, thus countering the heretics and those who choose to diverge from the beliefs of the predecessors and the custodians of [religious] tradition. (see Ibn Khaldūn 1984:1, 458)

Thus, in Ibn Khaldūn's view, kalām, in addition to providing genuine knowledge concerning religious doctrine and proving religious beliefs, is responsible for addressing and refuting the criticisms levelled at religious doctrine. Thus, drawing on these various definitions, it would be safe to say that kalām is the discipline responsible for bringing rational reasoning to bear on religious doctrine, supporting and reinforcing religious beliefs by virtue of rational and demonstrative proofs, and offering rational responses to the criticisms and objections raised by the critics.

The verbal equivalent for 'theology' in Arabic is 'ilāhīàt' or 'the divine sciences' (al-'ulūm al-ilāhīa). Apparently, this gained prevalence in Islamic tradition after Ibn Sīnā entitled the section on the first philosophy of his al-Shifa by the term (see Ibn Sīnā 1:4). This is a later phenomenon in Islamic literature, marked with its own historical characteristics, for example, a new phase of interaction between Islamic philosophy (Falsafa) and Kalām. However, and regardless of the lexical connections, the word 'theology' conventionally and more often, is taken to be an equivalent for the science of Kalam, which is the case in this article. As such, Theology (Kalām) means the study of Islamic doctrinal beliefs. Early examples of these doctrines included divine attributes and their relation to God, human free will and divine providence, divine justice and predestination, and the nature of divine revelation. As can be seen, Kalam covers a wide range of discussions over beliefs and doctrinal principles, as opposed to jurisprudential, legal and more generally, the practice and ritual-related aspects of Islam.

\section{The views of Sunni scholars regarding Kalām}

As already noted, Muslim scholars are divided on the legitimacy of studying and engaging in the discipline of kalàm. The supporters of this discipline are not content with merely asserting the legitimacy of this discipline but rather go further, deeming its pursuit to be a priority in comparison with the other branches of the Islamic studies. The detractors, however, proclaim the pursuit of kalām to be impermissible and thus deem Muslim theologians as worthy of condemnation. What follows is a detailed investigation of these two opposing positions.

\section{Advocates of the legitimacy of Kalām}

Many Muslim thinkers, predominantly the followers of the Ash'arī school of kalām and those of the Māturīdī school (the latter which, in contrast to the former school, identifies itself with the Hanafī school of Islamic jurisprudence) commend the discipline of kalam as the noblest form of human knowledge. For, they argue, its subject-matter is knowledge of God, and there is no subject that can be deemed nobler than God. As such, the pursuit of kalām should be encouraged, and in fact in the instances in which critics of religious faith raise objections regarding religious tenets, thus threatening to undermine the religious belief of the masses, learning this discipline in order to refute the raised objections is obligatory. To support their position, these scholars invoke the verses of the Qur'an and the example and thought of Prophet Muhammad's Companions (sahābah) and the Successors $\left(t \bar{a} b i^{\prime} \bar{u} n\right)$. Below is a treatment of the prominent Sunni scholars who endorse the discipline of kalām.

\section{Abū Hanīfah (d. $150 \mathrm{AH})$}

Abū Hanīfah Nu'mān ibn Thābit is among the advocates of the legitimacy of kalām. He is often hailed as the most preeminent master of the study of kalām (see 'Abd al-'Azīz Bukhārī $1418 \mathrm{AH}, 1: 17)$. He encouraged his students to pursue kalām and famously characterised the study of the principal tenets of faith as al-figh al-akbar ('the greatest knowledge'), as contrasted with the study of the practical laws of Islam, the shar''ah, which he described as al-figh al-asgahr ('the lesser knowledge'). This innovative characterisation is one obvious indicator of his favourable view of kalàm. Another no less obvious indicator is his authorship of a book on kalām entitled: al-figh al-akbar (see Bazdawī n.d.:3; Zarkashī 1421 AH, 1:17). The title of the book is self-explanatory. The reason given by the author for this designation is that its most prominent and widely debated topic is divine unity and attributes, knowledge of which is the 'greatest knowledge', and hence the title (see 'Abd al'Azīz Bukhārī 1418 AH, 1:17; Ibn Abī al-'Izz 1391 AH, 1:65; Taftāzānī 1401 AH, 1:6). This book had such an impact that it came to be known as the 'Book of Knowledge', and the arguments presented in it were described as offering the most effective proofs for refuting the opponents of religious faith (Isfarā'innī 1403 AH:184). Abū Hanīfah's contribution to kalām gained such widespread acceptance that some scholars maintained that those who truly wish to learn 'the science of polemics' ought to study Abū Hanīfah (Abū Ishāa Shīrāzī n.d., 1:78; Abū Shāmmah Maqdisī 1424 AH, 1:80; Mazī 1400 AH, 28:436).

\section{Abu al-Hasan Bazdawī (d. $382 \mathrm{AH}$ )}

Abu al-Ḥasan 'Alī ibn Muhammad Bazdawī, the great Ḥanafī jurisprudent of Transoxiana (Dhahabī $1405 \mathrm{AH}, 18: 602$ ), is 
another eminent Sunni scholar who wrote a book on kalām. This is how he described this discipline:

[Religious] knowledge is of two types: the knowledge of divine unity and attributes and the knowledge of the canonic law [shari'ah] and the rules of Islamic practice. What is crucial with regard to the former knowledge is to draw on the Scripture and the tradition and to avoid deviation (haw $\bar{a})$ and heresy (bid'ah). Our predecessors - including Abū Ḥanīfah, Abū Yūsuf, Muhammad, and their disciples - all exemplified this truth. Abū Hanīfah wrote the book al-Figh al-akbar on this topic, demonstrating therein the divine attributes, God's ordainment of good and evil.... (Bazdawī n.d.:3)

\section{Ibn Abī Zayd Mālikī (d. 386 AH)}

Abū Muhammad 'Abdullāh ibn Abī Zayd Qīrwānī Mālikī whom Dhahabī praises with such honorific titles as imām ('leader'), 'allāmah ('very knowledgeable'), qā'id ('leader'), faqih ('jurisprudent'), 'älim ahl al-maghrib ('the scholar to whom the Islamic West defers'), and al-mālik al-șaghìr ('the little Mālik') (see Dhahabī 1405 AH, 17:10) - describes kalām as the noblest science and that which is dearest to God (see Qīrwānī n.d.:169).

\section{Abū Hāmid Ghazālī (d. 505 AH)}

Abū Hāmid Ghazālī is arguably the most prominent Islamic theologian. That subsequent scholars used such reverential descriptions as shaykh ('the Master'), imām ('the leader'), bahr al-'ilm ('the sea of knowledge'), u'jübat al-zamān ('the marvel of all times'), zayn al-din ('the adornment of religion'), and dhakā' mufrit ('extremely clever'), to name only a few, to refer to him is a testimony to his unique status within Sunni kalām (see Dhahabī $1405 \mathrm{AH}, 19: 322$ ). His juridical affiliation lay with the Hanafī denomination, and in point of his theological orientation, he subscribed to the Ash 'arī school. To prove the legitimacy of the study of kalamm he cited a number of Qur'anic verses and then concluded, 'The Qur'an, from its beginning to its end, is all argumentation' (Ghazālī n.d., 1:95-96). Ghazālī emphasises the opinion that the value of the discipline of kalām is due to the goals that motivate the practitioner of kalamm and the dexterity of the practitioner with respect to those goals. These can include knowing the arguments for the creation of the world and the unicity of God, and having knowledge of the divine attributes (see Ghazālī n.d., 1:95).

\section{Badr al-Dīn Ibn Jamā'ah (d. $733 \mathrm{AH}$ )}

Badr al-Dīn Ibn Jamā‘ah Kanānī Shāfi ‘ī was a grand mufti and a senior judge, a Qur'anic exegete, and an eminent Ash'arī theologian (Dhahabī 1408 AH, 2:103). He wrote many works on kalām. Quoting Abū Manșūr 'Abd al-Qāhir Baghdādī, he enumerated the most prominent Sunni theologians, and among the Companions, he pointed to 'Ali ibn Abī Țâlib as the first practitioner of kalām on account of his debates with the Khawārij concerning the notions of divine promises and threats (al-wa'd wa al-wa $i d$ ), and with the Qadarīyyah regarding the issues of divine preordainment and predestination (al-qaḍa wa al-qadar). He named 'Abdullāh ibn 'Umar - who debated with the leader of the
Qadarīyyah, Ma 'bad Muhan̄ī, and disavowed them - as the next greatest theologian among the Companions (Ibn Jamā'ah, Muhammad, 1410 AH, 21-24).

\section{Shāțibī (d. $790 \mathrm{AH})$}

Abū Ishāa Shātibī, a prominent Mālikī jurisprudent, is of the view that by invoking the notion of 'the categorical interests' (mașālih mursalah), we are able to demonstrate that the discipline of kalām is in fact grounded in Islamic law and tradition and in the Qur'an. He reasons that kalām is nothing but the study of 'the principles of faith' (ușīl al-dīn), and as such its function is to articulate the arguments mentioned in the Qur'an and the corpus of tradition relating to the topic of divine unity and to other such topics that belong to the purview of the Islamic belief system (see Shâtibī $1429 \mathrm{AH}$, 1:29). This leads him to the conclusion that if in fact kalam and by extension all the disciplines that are in the service of the Islamic faith but that were absent in the earliest period of Islam - is an unorthodox innovation that ought to be shunned, then by the same logic we must also disavow the consolidation of the Qur'an into a single codex and the universally accepted practice of copying the Qur'an (see Shāțibī 1429 AH, 1:29).

\section{Ibn Abī al-'Izz Dimashqī (d. $792 \mathrm{AH}$ )}

'Alī ibn 'Alī ibn Muhammad Dimashqī, more commonly known as Ibn Abī al-'Izz, was a prominent Hanafī jurisprudent whose theological affiliation lay with the Māturīdī school of kalām. In his commentary on al- 'Aqìdah al-tahāwinyyah, he described kalām as the study of the principles of faith and thus as constituting the greater knowledge', in comparison with the study of the secondary tenets (fur '⿳亠口冋t) of faith, with which jurisprudence is concerned. Not only does he deem the pursuit of kalām permissible, but also consider it to be a need surpassing all other needs in importance and a necessity transcending all other necessities in significance. Furthermore, because of its unique role in providing knowledge of God and His attributes and actions, it is effective in engendering spiritual revival and inducing mental and emotional tranquillity in its students (see Ibn Abī al-'Izz 1391 $\mathrm{AH}, 1: 65)$.

\section{Aḥmad ibn Hasan Bayāọī (1098 AH)}

Kamāl al-Dīn Aḥmad ibn Hasan Bayāọ̄i is a renowned Māturīiñ theologian who adhered to the Hanafī school of Islamic law. He elaborated extensively on the legitimacy of pursuing kalām and puts forth a number of reasons demonstrating that kalām is the noblest of sciences. Bayāḍi maintained that possessing a greater knowledge of God and His attributes enhances the quality of one's worship. This connection between worship and knowledge is so strong. Bayāḍi emphasised that the proper performance of religious rituals is essentially dependent on an adequate comprehension of the principles of faith and of the science of kalām (see Bayāọ̄i 1425 AH:30-33). 


\section{Opponents of the legitimacy of Kalām}

In opposition to the scholars who have in various ways highlighted the significance of the discipline of kalām and have argued for its legitimacy, there are others who denounce this discipline and discourage its pursuit. The legitimacy of the study of kalām and the permissibility of its pursuit have come under attack from prominent authorities from all four schools of Sunni jurisprudence, for various reasons. In some of these cases, of course, the adopted stance is not as clear-cut as is sometimes suggested but is rather based on dubious quotations that are often at odds with other passages that seem to exhibit a positive stance toward kalām. Below, we will examine several examples of those authorities who are alleged to be opposed to the study of kalām.

\section{Abū Ḥanīfah}

Some Sunni scholars - most of whom are aligned with the Ahl al-Hadith movement (which espouses a very literalist interpretation of sacred texts) - cite certain passages from Abu Haniffah that seem to suggest that he was opposed to the study of kalām. These scholars claim that Abū Hanīfah declared the study of kalām to be forbidden (see Muqirrī, $1417 \mathrm{AH}, 1: 88)$, and that he condemned anyone as atheist (zindīq) who sought to approach religion by virtue of polemical disputation (jidāl) (see Khațīb Baghdādī $1403 \mathrm{AH}$, 2:159). Ibn Taymīyyah alleges, Abū Ḥanīfah would say, 'God curse "Amrw ibn 'Ubayd, for it was he who led the people to the study of kalamm and to beliefs that were irrelevant to them"' (Ibn Taymīyyah 1408 AH, 6:561). Similarly, it is claimed that when Abū Hanīfah was asked to answer a question regarding the philosophic notions of substance, accident, and body, he dismissed the assertions of philosophers as heretical (bid 'ah) and cautioned against learning kalām. As opposed to that, he encoured all people to adhere to 'the ways of the predecessors' (tarīqat al-salaf) (see Qāsimī 1399 AH, 1:298, and Abū Qāsim Ișfahānī 1419 AH, 1:115-116).

\section{Mālik ibn Anas (d. 179 AH)}

Mālik ibn Anas - the eponymous founder of the Mālikī school of Sunni jurisprudence - was one of the key figures in the formation of the Ahl al-Hadith movement within Islamic scholarship. He is said to have been opposed to the study of kalām. Harawī and Ibn Taymīyyah both quoted him as saying, 'Anyone who approaches religion through kalām will inevitably end up an atheist' (Anșān̄i Harawī 1418 AH, 5:71; Ibn Taymīyyah 1425 AH, 16:473).

\section{Abū Yūsuf Shaybānī (d. $182 \mathrm{AH}$ )}

Qāội Abū Yūsuf Shaybān̄ - an esteemed pupil of Abū Hanifah - is one of the authorities who is often cited as condemning kalām. The view that the practitioners of kalām are apostates is famously attributed to him (see Abū Țālib Makkī 1426 AH, 1:239; Ghazālī 1405 AH, 88; Ibn Qudāmah Maqdisī $1410 \mathrm{AH}, 41$; Wak̄̄‘ $1366 \mathrm{AH}, 3: 258)$. It is also reported that he said, 'Knowledge of kalām is ignorance and ignorance of kalām is knowledge. Once someone gains mastery of kalām, he is liable to be called an apostate' (Abū Ṭālib Makkī 1426 AH, 1:258; Dārumī 1433 AH:33; Șāliḥ̄ 1417 $\mathrm{AH}, 1: 17)$.

\section{Imām Shāfi'ī (d. 204 AH)}

Muhammad ibn Idrīs Shāfi ‘̄̄ (the eponymous founder of the Shäfi'í school of Sunni jurisprudence) is cited as another prominent opponent of the discipline of kalām. He is the source of many of the most scathing criticisms of kalām. One of the many notable remarks in this connection that is attributed to him is: 'It is necessary to shun kalām and flee from it as one would flee from a lion' (Abū Qāsim Ișfahānī $1419 \mathrm{AH}, 1: 224)$. The reason why Imām Shāfi ‘'̄ was so vehemently opposed to kalām is expressed in the following passage quoted from him:

Shun kalām, for if one is asked concerning a juridical question, and one gives the wrong answer, such as, say, if someone is asked concerning the blood money for the murder of another soul and he answers that it is an egg, he would only be laughed at. But if someone is asked concerning a theological question and he offers an incorrect answer, he would be denounced as an apostate. (Sam‘ānī 1417 AH:9)

\section{Ahmad ibn Hanbal (d. 241 AH)}

Ahmad ibn Hanbal (the eponymous founder of the Hanbali school of Sunni jurisprudence) expressed the fiercest condemnations of the study of kalām. He denounced the leading figures of the various theological persuasions as heretics (see Abū Ṭālib Makkī 1426 AH, 1:172, 239; Ghazālī 1405 AH:87; Ibn Taymīyyah 1406 AH, 2:139; Sam'ānī 141:9; 'Umrānī 1999:1, 130), going so far as to proscribe social interaction with the practitioners of kalām (see Ibn Abū Ya'lā n.d., 1:334; Dhahabī 1407 AH, 18:91; Ibn Muflih Maqdisī 1417 $\mathrm{AH}, 1: 223)$. Ibn Hanbal pronounced the practitioners of kalām as ineligible for receiving divine salvation and deemed an interest in kalām as indicative of the presence of a perverse inclination toward deception (see Ibn 'Abd al-Birr $1398 \mathrm{AH}$, 2:95; Ibn Jawzī 1405 AH:102; Ibn Qudāmah Maqdisī 1410 AH:41).

\section{Analysis and evaluation}

The conflict of contradictory opinions regarding the legitimacy of the discipline of kalam presents a murky and confused historical picture of the debate over this very important study. This state is especially detrimental as what is at stake is more than just a theoretical position on an abstract field of study; it influences how one decides to deal with this discipline. This practical concern is further accentuated if we take account of the fact that to delegitimise the study of kalam would in effect stay the growth and development of the intellectual component of Islamic doctrine. This makes it all the more important that we examine and evaluate the reasons why the detractors of kalām assumed such a negative stance toward this discipline. To this end, we will group the various criticisms raised against this discipline into three main strands. We will see what issues gave rise to these criticisms and how they may be addressed. 


\section{First criticism: Absence of Kalām in the age of the companions}

One of the primary criticisms levelled against kalām is that Prophet Muhammad never engaged in or encouraged theological discussions and inquiries. The Prophet's sole preoccupation was to teach the practical precepts and rules of Islam. The Prophet did not say anything that could be interpreted as grounds for the legitimacy of kalām. Moreover, one would also be hard pressed to find any statement from the Companions that could be brought to bear on the question of the efficacy of kalàm. Thus, pursuing this discipline would be contrary to the example set by the Prophet and the Companions.

The fallacy of this criticism can be readily demonstrated. The Prophet, in line with the Qur'anic injunction 'and argue with them by virtue of that which is best' (Qur'an 16:125), was constantly debating and arguing with the unbelievers. His attitude in engaging with the unbelievers was informed by the Qur'anic dictum: 'Offer your argument if you are truthful' (Qur'an 2:111; also, Qur'an 21:24; 27:64; 28:75). And the reason for this Qur'anic approach is obvious, because with careful consideration of the contents of the Qur'an and the spirit that pervades its teachings, it will be seen that the Qur'an's call is founded on reason. With regard to the use of rational arguments, the Qur'an itself employs this method. Examples of the application of this method can be found in the Qur'an's use of a rational argument in its refutation of the polytheists' claim as to the divinity of their gods, namely, that one of the requisites of divine lordship is having the power to bestow benefits and being able to guard against affliction and harm [to one's subjects] (Qur'an 17:56 and 34:22). Another example can be found in the Qur'an's argument for the reality of the resurrection and the truth of the call of the Apostle of God to the fact that the creation of the heavens and the earth was not mere idle play (Qur'an 21:16-17). Verse 35:3 similarly argues for the exclusivity of God's Providential Lordship (rubūbiat) by averring that it is only He Who is the Creator. As the Qur'an states elsewhere, those who are condemned to divine torment as sinners and disbelievers merit such a sentence only if they have rejected the truth after being presented with clear evidence of its veracity, and those who merit the heavenly life in the hereafter do so only in light of conformity to clear proofs vindicating their beliefs (see Qur'an 8:42). The debate between Prophet Muhammad and the Christians of Najrān (alluded to in Qur'an 3:61) is another indication that Prophet Muhammad did not shun debates concerning theological topics and that he in fact was strongly driven to engage in theological debates when doing so was in defence of the intellectual principles of the Islamic faith.

Furthermore, the claim that the Companions did not endorse kalām is obviously erroneous. Because if what the critics have in mind is a practical refusal to engage in theological debates, which would be clearly at odds with historical fact. Numerous instances of debates in which the Companions engaged with unbelievers and even occasionally with Muslims are recorded in historical documents. One example is the debate that 'Abdullāh ibn 'Abbās had with the Khawārij at the behest of 'Alī ibn Abī Ṭālib (see Zamakhsharī 1412 AH, 2:66), and 'Alī ibn Abī Țālib's debate (see Ibn Bațtal 1423 AH, 10:326; Jariri Nahrawani, $1426 \mathrm{AH}, 600$ ), as well as the debates of $\mathrm{Abu}$ Bakr al-Siddīq (Lālaka'I 1402 AH, 4:663) with the Qadarīyyah. 'Alī ibn Abī Țālib's debate with the Khawārij (see Bukhārī $1418 \mathrm{AH}, 4: 472$ ) is another case in point. Historical records also point to 'Umar ibn Khațāab's debate with Jews regarding the Archangels Gabriel and Michael (see Ibn 'Abd al-Birr $1398 \mathrm{AH}, 2: 953)$. Many other instances of theological discussions held by such prominent Companions as Hasan Bașrī (see Balādhurī 1417 AH, 2:147) and 'Abdullāh ibn Mas'ūd are described in authoritative historical texts (see Ghazālī 1405 AH:96). Another example can be found in a debate that took place between a group of the Prophet's associates and a Christian or Jew (a member of the community of 'People of the Book') concerning the issue of destiny or God's providence and divinely ordained 'fate' (qaḍa wa qadar) (Shaybān̄i 1400 AH, 1:153; Tabarānī 1404 AH, 8:153). Also, the Prophet's associates would engage in rational argumentation with each other or with others in the presence of the Prophet (unto whom be God's peace) without their being prevented from doing so by the Prophet (Balādhurī 1417 AH, 2:147; Ibn Qayyim al-Juwzīya 1415 AH, 3:594). But if what the critics have in mind is that the Companions never pursued and taught kalamm as a codified field of knowledge, the same can be said with regard to such other disciplines as tafsir (Qur'anic exegesis), hadith (the study of the reports related from the Prophet and the Companions), and figh (jurisprudence). None of these disciplines, which all the detractors of kalām find to be perfectly credible and consistent with Islamic faith, had formally taken shape during the time of the Companions (see Ghazālī n.d., 1:96).

If, on the other hand, the thrust of the criticism concerns the use of such novel terms as substance and accident, which were borrowed from Hellenistic philosophy, the criticism would lack any substantive value, for these terms are not critical to the study of kalamm; they only facilitate a more convenient way of communicating between the scholars and the students of kalàm. Moreover, the same phenomenon is at play in the other disciplines of the Islamic studies, as figh and hadith developed terms that were definitely not in use during the time of the Prophet or the Companions (see Ghazālī n.d., 1:95).

But if the criticism intends to point to the fact that theological debates and discussions were not prevalent during the time of the Companions, the answer is clear. In the early years of Islam, there was not much theological and sectarian dissension, and therefore there was no need to engage in theological disputation. Only toward the middle and the end of the age of the Companions did sectarian and theological divisions start to emerge. With the formation of such sects as the Khawārij and the Qadarīyyah, the Companions in fact 
started articulating sound and robust arguments in critique of the divergent beliefs of these newly formed sects. They would engage in serious debates with the prominent figures of these sects and would attempt to offer reasonable responses to their claims. For example, Abdullah ibn Abbās participated in a debate which he referred to as majles-i sir $\bar{a}^{\prime}$ in which he would engage in rational argumentation concerning the issue of destiny or God's providence and divinely ordained 'fate' (qaḍa wa qadar) (Al-Janadī 1995, 1:99).

\section{Second criticism: Adverse consequences}

The second strand of criticism levelled against the study of kalām is based on the ostensible adverse consequences of this discipline. According to some of the detractors of this discipline, pursuing kalām can only lead to bigotry, greater polarisation and division, and enmity among Muslims, and these are all consequences that are strongly condemned in Islam (see Ghazālī n.d., 1:95).

The fallacy in this line of criticism is that it attributes the adverse consequences entailed by the incorrect methods and presuppositions utilised by some theologians to the discipline of kalām as such. Kalām itself is based on principles derived from the Qur'an and the corpus of tradition, and any negative consequence that may result from the pursuit of kalamm is caused by the illegitimate methods and principles employed by some of its practitioners (see Ghazālī n.d., 1:95). When contemplating the legitimacy of kalām as such, what we need to bear in mind is that when the proper methods and principles are utilised, the results arrived at (namely, defending Islamic beliefs and offering cogent and convincing arguments to those who raise questions and criticisms about Islamic doctrine) will be legitimate and reasonable, and this is true of all the branches of Islamic studies. With the other disciplines, too, be it figh, hadith, or rijäl, if the practitioner implements incorrect principles and methods, the results and consequences he will arrive at would naturally be invalid and illegitimate. But, it would be incorrect to cite these invalid and illegitimate consequence as grounds for undermining the legitimacy of the disciplines in question. Abū Hāmid Ghazālī makes the following observation in this connection:

If the study of kalām leads to bigotry, division, rancour, and enmity, these are obviously unacceptable matters, and we must all avoid them. But in the same vein, arrogance, conceit, ostentation, and seeking after social and political power, which are potential consequences that may be attendant on the pursuit of such universally accepted disciplines as hadith, figh, and tafsìr, are never cited as grounds for the illegitimacy of the disciplines in question. (Ghazālī n.d., 1:94-96)

\section{Third criticism: Opposition of major religious leaders}

The third, and arguably the most significant, criticism directed at the study of kalam is the opposition voiced by prominent Sunni religious leaders against this discipline. To address this criticism, it is essential that we correctly and carefully analyse and examine the expressions of opposition purportedly voiced by the religious leaders in question. It is only through such an analysis that we can discover their true intent.

We will start with an examination of the negative attitude ostensibly exhibited by Abū Hanīfah. As extensively demonstrated in the section 'The Advocates of the Legitimacy of Kalām', Abū Hanīfah is known more for his support of the study of kalām than for his opposition. The positive remarks attributed to Abū Hanifah that are supportive of the legitimacy of the study of kalām far outweigh those that are deemed to be critical. But as for why Abū Hanīfah could have held a positive opinion of kalām despite the negative remarks he occasionally expressed regarding it, the exposition that numerous Sunni scholars have offered of the views of Abū Hanīfah in this relation are enlightening. Adducing the reports indicative of Abū Hanīfah's positive stance toward kalām, Dhahabī offers the following explanation regarding the negative remarks attributed to him:

Abū Hanīfah was not opposed to kalām as such but to certain theological topics and to certain practitioners of theology, such as 'Amrw ibn 'Ubayd, who was one of the prominent figures of the Qadarīyyah and Mu'tazilī schools. He did not reject kalām per $s e$, that is to say, as the discipline responsible for delineating and defending the boundaries of faith. (Dhahabī 1405 AH, 6:104)

The same analysis is true of the apparently negative views expressed by Abū Yūsuf Shaybānī regarding kalām, which at first glance seem to imply its illegitimacy. His criticism was mainly aimed at those practitioners of kalām that exploited this study for improper objectives, employed invalid methods, and attacked their theological adversaries as heretics. A careful examination of the modifiers in Abu Yūsuf's remarks makes it clear that he was not opposed to the discipline of kalām as such. Rather, he was averse to such figures as Marrīsī and to such persuasions as the Jahmìyyah and the Mu'tazilah who bickered unduly regarding the divine attributes and accused one another of apostasy. This is how Dhahabī explains Shaybānī's apparent opposition to kalām:

The examples Abū Yūsuf has in mind in denouncing kalām are the doubts and objections that arise in consequence of the views of the practitioners of kaläm. They would bicker with one another regarding the verses [ $\bar{a} y \bar{a} t]$ and reports $[a h \bar{a} d \bar{i} t h]$ bearing on the topic of the divine attributes and would denounce one another as heretics in virtue of their differing views. It was this [problematic] approach that resulted in the emergence of the Mu'tazili and Jahmī persuasions and the theory of the corporeality of God [tajsìm] and many other woes. (Dhahabī 1405 $\mathrm{AH}, 8: 539)$

Likewise, Shāfi 'î́'s denunciation of all practitioners of kalām was motivated by his encounters with Abū Yahyā Ḥaf̣̣ Fard. He believed the Qur'an to have been created in time, and it was on this question that Shāfi' ${ }^{\prime} \overline{1}$ debated with him (see Dhahabī $1405 \mathrm{AH}, 10: 30$ ). What Dhahabī's report indicates is that Shāfi 'î́'s disapproval of kalām and his denunciation of the practitioners of kalām as heretics was aimed only at those who claimed that as the word of God, the Qur'an was a temporal phenomenon or one that was created 
in time. This qualified opposition was described by some later writers, erroneously, as a categorical opposition, whereas other writers correctly highlighted the qualified scope of Shāfi 'î's opposition. It is from the reports of the latter group of writers that we may accurately understand Shāfi ' $\bar{i}^{\prime}$ s true stance toward kalām. Ibn 'Asākir, quoting Bayhaqī, points to this very fact in his elucidation of Shāfi ' $\overline{1}^{\prime}$ 's position, and then he adds,

How could the object of Shāfi 'i's's denunciation be the kalām of the followers of genuine Islamic tradition [ahl al-sunnah] and the majority view [al-jama $a h]$ when in fact he himself would expose the falsehood of the arguments and deceptions of the followers of the deviant sects [ahl al-ahwa'] that had made an impression on those with whom he was acquainted. (Ibn 'Asākir 1404 AH:341)

Another critic of the discipline of kalam $m$ who is described as exhibiting a very negative attitude toward this discipline is Ahmad ibn Hanbal. A consideration of his times and the historical conditions and events that defined his social environment can be of great help in correctly understanding the disapproving remarks quoted from him regarding the study of kalām. Ibn Hanbal's time saw the most intense phase in the dispute between the Ahl al-Hadith (who advocated for a very literalist approach toward an understanding of sacred texts) and the Mu'tazili theologians, especially with regard to the question of the createdness of the Qur'an. The dispute was so intense that it was characterised as a fitnah - an instance of religious dissension. The debate was such a prominent social phenomenon that in $218 \mathrm{AH}$ the Abbasid caliph Ma'mūn ordered the governor of Baghdad to 'test' the judges, jurisprudents, and reporters of Prophetic tradition with the question of the creation of the Qur'an. Those who believed in the creation of the Qur'an were free to go, but those who believed otherwise were to be reported to the caliph (see Ibn Athīr Jazarī 1417 AH, 5:572). Ahmad ibn Hanbal was one of the figures who resisted the governor's pressure, ultimately leading to his arrest and his forcible transfer to the court of Ma'mūn while bound and in shackles. He remained in prison for his refusal to believe in the creation of the Qur'an until the ascension of Mutiwakkil to the caliphate (see Ibn Athīr Jazarī 1417 AH, 5:576).

Under the caliphate of Mutiwakkil, the tables were turned in favour of the Ahl al-Hadith and to the detriment of the Mu'tazilī theologians. Ahmad ibn Hanbal and all those imprisoned for rejecting the createdness of the Qur'an were freed and belief in the creation of the Qur'an was banned. Mutiwakkil issued a decree, effective in all Islamic lands, that prohibited the study of kalām and the belief in the creation of the Qur'an (see Ibn Kathīr 1424 AH, 14:350). This clearly indicates that in that day and age, kalām was used exclusively to refer to the debate over the creation of the Qur'an.

The foregoing interpretation is further corroborated by another statement made by Ibn Hanbal in this relation. He is said to have remarked, 'Those who study kalām will never attain salvation, for they are not immune from being persuaded into accepting the Jahmī position' (Dhahabī 1405
AH, 11:29, 1407 AH, 18:90; Ibn Muflih Maqdisī 1417 AH, 1:223). This quote once again shows that the object of Ibn Hanbal's opposition was not kalamm as the discipline responsible for arguing for and defending the articles of faith but as a harmful preoccupation with such contentious topics as the creation of the Qur'an and the nature of the divine attributes, which he deemed to be heretical. This understanding is reinforced by the historical fact that Ibn Hanbal would himself engage in theological debates with theologians belonging to the Mu'tazilah, Qadarīyyah, and Jahmìyyah sects, attempting thereby to put pressure on his theological adversaries and convince the caliph to endorse his theological position on the issues in question.

Ibn Taymīyyah and Bayāḍī both agree with this interpretation of Ibn Hanbal's position. Ibn Taymīyyah explained that Ibn Hanbal employed valid rational arguments in defending the religious beliefs of Islam. However, if the arguments adduced in theological discussions were contrary to the contents of the Qur'an and Islamic tradition or involved some unorthodox innovation, Ibn Hanbal was quick to dismiss them. In a letter he wrote to Mutiwakkil explaining his position, Ibn Hanbal stated,

I do not favour kalām, unless it aligns with a verse in the Qur'an or a report related from the Prophet, the Companions, or the Successors in the corpus of tradition. (Ibn Taymìyyah $1417 \mathrm{AH}$, 7:155)

Kamāl al-Dīn Bayāọ̄ī agreed with Ibn Taymīyyah's assessment. He explained that the kalām that was the object of Ibn Hanbal's denunciation was the kalām that was articulated by deviant and heretical sects (ahl al-ahwā' wa al-bid'ah), not the discipline of kalām as such (see Bayāḍī 1425 $\mathrm{AH}: 37)$.

\section{Discussion}

Having analysed the views of the proponents and detractors of kalām, we demonstrated that from the Islamic standpoint, the application of reason to the principal or creedal doctrines of faith is legitimate. This then led us to conclude that denouncing the practitioners of kalām as heretics on the basis of their use of rational argumentation is unfounded. The only genuine ground that the detractors of kalām invoke in support of their stance is the critical statements of the prominent scholars of Islamic jurisprudence and theology regarding the illegitimacy of pursuing the study of kalām. We showed, however, that when viewed in light of the socio-political conditions of their time, these statements are insufficient in proving that the persons in question were in fact opposed to the discipline of kalām as such.

The second and third centuries $\mathrm{AH}$ were a time of intense conflict between the Mu'tazilah and the other doctrinal persuasions in Islam. The Ahl al-Hadith movement, represented by such influential figures as Mālik, Shāfi ‘'i, and Ibn Hanbal, was fiercely opposed to the Mu'tazilah. As the application of the term kalām to the discipline responsible for defending the articles of Islamic faith was first popularised 
by the Mu'tazilah, the designation mutikallim (student or practitioner of kalām) was used by the members of the Ahl al-Hadīth movement to refer exclusively to $\mathrm{Mu}^{\text {'tazili }}$ theologians. This reference was aided by the fact that the most contentious issue faced by the scholars and that indicated the rift between the Ahl al-Hadith movement and Mu'tazili theology was the precise nature of 'the word of God' (kalām allāh) as manifested in the Qur'an, and whether it was a temporal phenomenon created in time (hädith) or an eternal being (qadim).

Furthermore, the Mu'tazilites were pejoratively labelled as 'ahl al-ahwa') literally meaning 'those given to whims and desires' because, all other things being equal, they considered the value of rational arguments as being on a par with the Qur'an and the hadith report corpus. Thus, the senior scholars in the 'scripturalist' school (ahl al-hadith) opposed them. This in fact is how the opposition to the science of kalām arose (Ibn Asākir 1404 AH:345). Additionally, the opposition of these jurists against the science of kalām and its advocates was not because they used neologisms such as 'attribute', 'substance', and 'corporeity'. Instead, it was because of [their belief] that they disseminated deviant beliefs which contravened [the teachings of] the Qur'an, the hadith report corpus, and plain reason (see Ibn Taymìyyah 1417 AH:vol. 1, 232-233).

In addition to all this, many of the major Sunni religious leaders, first and foremost among them being Abü Hanīfah, described kalām as 'the noblest of the sciences'. A number of them asserted that learning kalām in order to be able to respond to criticisms of Islamic doctrine is obligatory and teaching it to others is mandatory. In light of the inherent purpose of the discipline of kalamm, which is to offer a rational account and defence of the doctrines of faith, a favourable stance toward the discipline of kalām as we understand it today is more reasonable and in greater agreement with the Qur'an, with Islamic tradition, and even with the expressed position of the most prominent Sunni jurisprudents and religious leaders, including those who denounce the practitioners of kalām as heretics. For, these seemingly unapologetic detractors were themselves, in a sense, practitioners of kalām, as they would argue against those beliefs and sects that in their view contradicted orthodox doctrine, and to this end they would engage in theological debates and write numerous texts of a theological character.

\section{Conclusion}

This study sought to answer the question as to why some of the well-known figures among Sunni scholarship anathemised (pronounced takfir upon) the practitioners of kalām (mutikalliminn); and whether the subject of their anathemisation included everyone engaged in creedal theology or whether their criticism was limited to specific groups who harboured specific objectives in specific (and more limited) theological controversies.
In response to the above questions, the following points were established in this article:

1. The prohibition of kalām and the excommunication of its practitioners by scholars such as Abū Hanīfa Nu'mān ibn Thābit, Mālik ibn Anas, Muhammad ibn Idrīs al-Shāf'ì, and Ahmad ibn Hanbal, and the like, has nothing to do with the later concept of kalām as it is commonly understood among Muslim scholarship. Rather, the main objective of those who advocated such prohibitions was to oppose a particular side in certain controversies such as the one over the createdness of Qur'an as the word of God, and/or targeting a specific group among the mutikallimin (Kalam practitioners), who disseminated certain (believed to be heretic) beliefs of specific sects such as the Mu'tazilites, the Qādirīya, and the Jabrīya. The intention was not an all-encompassing ban on kalām as the science of understanding doctrinal beliefs and defending religious dogma. Kalām as a general category of that discipline was never a controversial issue.

2. Many senior Sunni figures such as Abu Hanīfa, Abu al-Hasan al- Bazdawī, Abu Zayd Qirawāni al-Māliki, Abu Hamid al-Ghazāli al-Shafi ‘'i, Badr al-Din Ibn Jamā‘a, Abu Ishāq al-Shātibi, Ibn Abi'l'Az al-Dimashqi, Kamāl al-Dīn Bayāọī, Imām al-Harmayn alJuwayni, and so on, consider the study of kalam as a legitimate practice and [some of them] have even issued religious verdicts (fat $\bar{a} w \bar{a})$ that learning the science of kalām for apologetic purposes, that is, defending the religion and its creeds in the face of disbelievers' intellectual attacks, is a religious obligation (wäjib).

3. Objections and counterarguments such as 'that the Prophet and his companions did not practise Kalam' or the ones based on the negative consequences of studying it, and so on, were thoroughly examined. It was concluded that these objections do not serve as plausible grounds for the prohibition against kalam, and that the arguments for its legitimacy prove to be stronger and more logical, considering their compatibility with the verses of the Qur'an, the hadith report corpus, and the tradition-setting practice of the early companions of the Prophet, as well as the scholars in the formative period of Islam (ulamā-i salaf).

\section{Acknowledgements Competing interests}

The authors declare that they have no financial or personal relationships that may have inappropriately influenced them in writing this article.

\section{Authors' contributions}

Both authors contributed equally to the writing of this article.

\section{Ethical considerations}

This article followed all ethical standards for research without direct contact with human or animal subjects.

\section{Funding information}

This research received no specific grant from any funding agency in the public, commercial or not-for-profit sectors.

\section{Data availability}

Data sharing is not applicable to this article as no new data were created or analysed in this study. 


\section{Disclaimer}

The views and opinions expressed in this article are those of the authors and do not necessarily reflect the official policy or position of any affiliated agency of the authors.

\section{References}

Abū Isḥāq Shīrāzī, I., n.d., Tabaqāt al-fuqahā' [The successive generations of jurisprudents], K. Alamīs (ed.), Dār al-Qalam, Beirut.

Abū Qāsim Ișfahānī, I., 1419 AH, al-Hujjah fi bayān al-mahajjah wa sharh 'aqīdat ah al-sunnah [The proof in elucidating the path and an exposition of the belief of the followers of tradition], Dār al-Rāyah, Riyadh.

Abū Shāmmah Maqdisī, 'A.a-R., 1424 AH, Khuțbat al-kitāb al-mu'ammal li al-radd ilā al-amr al-awwal [Prelude to the anticipated book on returning to the primary state], J. 'Izzūn (ed.), Maktabat Aḍā' al-Salaf, Riyadh.

Abū Ṭālib Makkī, M., 1426 AH, Quwwat al-qulūb [The strength of the hearts], 'Ā.l. Kayālī (ed.), Dār al-Kutub al-'Ilmīyyah, Beirut.

Abū Ya'lā, M., n.d., Tabaqāt al-hanābalah [The successive generations of hanbalî scholars], M.H. Alfaqī (ed.), Där al-Ma'rifah, Beirut.

Al-Janadī, B. A.-D.M., 1995, As-Suluk fi Tabaqāt al-'Ulema wa'l-Muluk [Behavior in the layers of scientists and kings], Maktabat al-Ershad, Sanaa.

Anșārī Harawī, 'A., 1418 AH, Dhamm al-kalām wa ahlih [Condemnation of kalām and its practitioners], edited by 'Abd al-Rahmān 'Abd al-'Azīz Shabal, Maktabat al'Ulüm wa al-Hikam, Medina.

Baghawī, H., 1403 AH, Sharh al-sunnah [Elucidation of tradition], S. Arna'ūț (ed.), Maktab al-Islami, Beirut.

Balādhurī, A. ibn Yaḥyā ibn Jabir,1417 AH, Ansab al-Ashraf [Lineage of the nobles], Dār al-Fikr, Beirut.

Bayāọ̄i, A., $1425 \mathrm{AH}$, Ishārāt al-marām min 'ibārāt al-imām [Indications pointing to endorsed viewpoint from the writings of the imam], S.Y. 'A. al-Razzāq Shāfi'î (ed.), Zamzam Bilbishirz, Karachi.

Bazdawī, 'A., n.d., Kanz al-wușūl ilā ma'rifat al-ușūl [The treasure of arriving at the knowledge of the principles], Mațba'at Jāwīd Brīs, Karachi.

Bukhārī, 'Abd al-'Azīz, 1418 AH, Kashf al-asrār [Discovering the mysteries], 'A.M.M. 'Umar (ed.), Dār al-Kutub al-'Ilmìyyah, Beirut.

Dārumī, 'U., 1433 AH, Naqd 'uthmān ibn sa'îd 'alā al-marrīīi [The critique by Ibn Sa'îd of al-Marrīsī], A.'Ā.S. Atharī (ed.), Maktabah Islāmīyyah, Cairo.

Dhahabī, M., $1405 \mathrm{AH}$, Sìyar a'lām al-nubalā' [The lives of the noble personages], Mu'assisat al-Rasālah, Beirut.

Dhahabī, M., 1407 AH, Tārīkh islām wa wafayāt al-mashāhīr wa al-a'lām [The history of Islam and the deaths of famous individuals and personages], 'U.'A. al-Salām Tadmurī (ed.), Dār al-Kitāb al-'Arabī, Beirut.

Dhahabī, M., 1408 AH, Mu'jam shuyūkh kabīr [Dictionary of the great masters] Maktabat al-Șiddīq, Taif.

Ghazālī, M.I.M., n.d., Ihyā' Ulūm al-Dīn, Dār al-Ma'rifa, Beirut.

Ghazālī, M., 1405 AH, Qawā'id al-'aqā'id [The rules of the beliefs], M.M. 'Alī (ed.), 'Ālam al-Kutub, Beirut.

Ibn 'Abd al-Birr, Y., 1398 AH, Jāmi' bayān al-'ilm wa faḍlih [A comprehensive elucidation of knowledge and its virtue], Dār al-Kutub al-'ilmīyyah, Beirut.

Ibn Abī al-'Izz, M., 1391 AH, Sharh al-'aqīdah al-țahāwīyyah [An exposition of Tahāwīyyah belief], Maktab Islāmī, Beirut.

Ibn 'Asākir, 'A., 1404 AH, Tabyīn kidhb al-muftarī [Exposing the falsehood of the falsifier], Dār al-Kitāb al-'Arabī, Beirut.

Ibn Athīr Jazarī, 'A., 1400 AH, al-Lubāb fi tahdhīb al-ansāb [A summary revised survey of genealogy], Dār Șadr, Beirut.

Ibn Athīr Jazarī, 'A., 1417 AH, al-Kāmil fi al-tārīkh [A comprehensive study of history], Dār al-Kitāb al-'Arabī, Beirut.

Ibn Bațtah, 'U., $1415 \mathrm{AH}, a l-I b a ̄ n a h ~ a l-k u b r a ̄$ [The greater book of distinction], Dār al-Rāyah, Riyadh.

Ibn Batțal, 'A. al-Hasan Ali ibn K., 1423 AH, Sharh Sahih al-Bukhari le Ibn Battal [Explanation of Ibn Battaal on Sahih Bukhari], Maktab Rushd, Riyadh.
Ibn Jamā'ah, M., 1410 AH, İdāh al-dalīl fi qat' hujaj ahl al-ta'tīl [An exposition of reasons against the proofs of the negators], Dār Salām li al-Tabā'ah wa alNashr, Cairo.

Ibn Qayyim al- Juwzīya, S. al-Dīn Abū 'Abd A.M., 1415 AH, Zad al-Ma'ad fi Hadyi Khairi-l' Ibad, [Provision of the hereafter, from the Guidance of Allah's Best Worshipper], Al-Risalah Institute, Beirut.

Ibn Kathīr, I., 1424 AH, al-Bidāyah wa al-nihāyah [The beginning and the end], 'A. ibn 'Abd al-Muhsin Turkī (ed.), Dār Hijr, Beirut.

Ibn Khaldūn, 'Abd al-Rahmmān, 1984, Muqaddamat ibn khaldūn [The preliminaries by Ibn Khaldun], Dār al-Qalam, Beirut.

Ibn Muflih Maqdisī, M., 1417 AH, al-Ādāb sharîyyah wa al-minah al-marīiyyah [Religious proprieties and notable virtues], S. Arna'ūṭ (ed.), Mussasisat al-Rasālah, Beirut.

Ibn Qudāmah Maqdisī, 'A., 1410 AH, Tahrīm al-nazar fi kutub al-kalām [Proscribing the study of the books of theology], 'Ālam al-Kutub, Riyadh.

Ibn Taymiyyah, A., 1406 AH, Minhāj al-sunnah al-nabawiyyah [The pathway of the prophetic tradition], Mu'assisat Qirțabah, Cairo.

Ibn Taymīyyah, A., 1408 AH, al-Fatāwā al-Kubrā [The greater book of juridical pronouncements], Dār al-Kutub al-'Ilmīyyah, Beirut.

Ibn Taymiyyah, A., 1417 AH, Dar' ta'ârud al-'aql wa al-naql [Averting the conflict of reason and doctrine], Dār al-Kutub al-'Ilmīyyah, Beirut.

Ibn Taymīyyah, A., 1425 AH, Majmū' al-fatāwā [Collection of juridical pronouncements], 'A. al-Raḥmān ibn Muḥammad (ed.), Maktabat Ibn Taymīyyah, Cairo.

İjī, 'Abd al-Raḥmān, 1417 AH, al-Mawāqif [The stations], 'A. al-Raḥmān 'Umayrah (ed.), Dār al-Jīl, Beirut.

Jariri Nahrawani, Mu'afa ibn Zakarya bin Yahya 1426 AH, Jalīs al-șāliḥ al-kāfi wa-al-anīs al-nāșih al-shāfi, Dār al-Kutub al-'Ilmīyyah, Beirut.

Khațīb Baghdādī, A., 1403 AH, Jāmi' li akhlāq al-rāwī wa ādāb al-sāmi' [A comprehensive account of the rules to be followed by narrators and the instructions to be heeded by the recipients], Maktabat al-Ma'ārif, Riyadh.

Lālaka'I, H.A. al-Qasom, 1402 AH, Syrhu Ushul I'tiqad Ahlu Al-Sunnah Wa Al-Jamaah [Explanation of the origins of Ahl al-Sunnah beliefs], Dar al-Tayebeh, Riyadh.

Mazī, Y., $1400 \mathrm{AH}$, Tahdhīb al-kamāl [A revision of the book of perfection (by Abū Muhammad 'Ábd al-Ghanī ibn 'Abd al-Wāhid)], B. 'A. Ma'rūf (ed.), Mu'assisat alRasālah, Beirut.

Muqirrī, 'Abd al-Rahmān, $1417 \mathrm{AH}$, Ahādīth fï dhamm al-kalām wa ahlih [Reports condemning theology and its practitioners], Dār Ațlas, Riyadh.

Muzaffar, M., $1422 \mathrm{AH}$, Dalō'il al-sidq li nahj al-haqq [The proofs of the truth of the true path], Mu'assisat Āl al-Bayt, Damascus.

Qāsimī, M.J. al-Dīn, 1399 AH, Qawā'id al-taḥdīth [The rules of narration], Dār al-Kutub al-'llmīyyah, Beirut.

Qīrwānī, 'A., n.d., Risālat ibn abī zayd qīrwānī [The treatise of Ibn Abī Zayd al-Qīrwānī], Dār al-Fikr, Beirut.

Sālihī, M.A.D., 1417 AH, Sharh al-Aqīda al-Tahawīa, Mu'assissa al-Risāla, Beirut.

Sam'ānī, M., $1417 \mathrm{AH}$ Intisāar li așhāb al-hadīth [The victory of the traditionists], M. ibn Ḥusayn Jīzānī (ed.), Maktabat Aḍwā’ al-Minār, Riyadh.

Shahrastānī, M., 1404 AH, al-Milal wa al-niḥal [Faiths and denominations], M.S. Kīlānī (ed.), Dār al-Ma'rifah, Beirut.

Shāțibī, I., 1429 AH, al-I'tișām [Adherence], M. ibn 'Abd al-Raḥmān Shaqīr (ed.), Dār Ibn al-Jawzī, Riyadh.

Shaybānī, Ibn Abī Asim, Abu Bakr Ahmad ibn Amr, 1400 AH, Kitab al-Sunnah [tradition book], N. al-albani (ed.), Maktab al-Islami, Beirut.

Tabarānī, S.ibn A., 1404 AH, Al-Mu'jam al-Kabir [Al-Tabarani's grand collection of Hadith], Research by Hamdi ibn Abdul Majid AL-Salafi, Maktab Al-Zahra, Musal.

Taftāzānī, Sa'îd al-Dīn, 1401 AH, Sharh maqāșid fỉ 'ilm al-kalām [An exposition of the objectives of the science of theology], Dār Ma'ārif Nu'mānīyyah, Peshawar.

Wakī', M., $1366 \mathrm{AH}$, Akhbār al-quḍāh [Tales of judges], Maktabat al-Tijārīyyah al-Kubrā, Cairo.

Zarkashī, M., $1421 \mathrm{AH}$, Baḥr al-muhīṭ fi ușūl al-figh [The encompassing ocean: On the principles of jurisprudence], Dār al-Kutub al-'Ilmīyyah, Beirut.

Zamakhsharī, J.M., 1412 AH, Rabi al-Abrar wa nusus al-Akhbar [Spring of the righteous and the texts], Al-Aalami Foundation for Publications, Beirut. 